\title{
Allozyme variation of Pinus pallasiana D. Don in Natural Crimean populations and in plantations in technogenously-polluted areas of the Ukraine steppes
}

\author{
Ivan I. KORSHIKOV**, Fulvio DUCCI ${ }^{\mathrm{b}}$, Natalia S. TERLIGA ${ }^{\mathrm{a}}$, Serguey A. BYCHKOV ${ }^{\mathrm{a}}$, \\ Elizaveta M. GORLOVA ${ }^{\mathrm{a}}$ \\ a Dept. of Plant Tolerance Physiology, The Donetsk Botanical Gardens, Prospekt Ilyicha 110, Donetsk, 83059 Ukraine \\ b Coordinator IUFRO WP 20213, Ist. Sperimentale per la Selvicoltura, C.R.A. - Council for Research and Experimentation in Agriculture, \\ viale S. Margherita 80, 52100 Arezzo, Italy
}

(Received 16 August 2002; accepted 6 November 2003)

\begin{abstract}
Allozyme variation parameters have been estimated and compared among four $P$. pallasiana D. Don plantations located in the Ukraine steppes and in three Crimea natural populations. The analyses also concerned three groups of trees selected for their possible tolerance/ resistance to steppe conditions and to industrial pollution. The polymorphic loci percentage in the natural populations varied from 0.74 to 0.89 and the allele mean number varied from 2.4 to 2.7. Among the artificial plantations these values varied from 0.75 to 0.85 and from 2.35 to 2.75 respectively. Heterozygote deficiency (14.9\%) was characteristic of 6 of the 7 stands examined. Instead, a heterozygote excess (14.6 to $36.9 \%)$ but less allele diversity, was revealed among groups of selected trees. Nei's genetic distances averaged to 0.010 when comparing natural and artificial populations. Parameters measured on selected groups and on natural populations from the steppes showed an absence of inbreeding depression. The results of this study lead to a recommendation that these trees be used as the basic material in extensive plantation programs of $P$. pallasiana in the Ukraine steppes, including polluted areas.
\end{abstract}

Pinus pallasiana D. Don / Ukrainian steppe / allozyme variation / polluted areas / selection

Résumé - Variation alloenzymatique chez Pinus pallasiana de populations naturelles en Crimée et de peuplements plantés dans des zones industrielles polluées de la steppe ukrainienne. Les paramètres de variation alloenzymatique de 4 peuplements de Pinus pallasiana plantés dans la steppe ukrainienne de Pinus pallasiana et de 3 populations naturelles en Crimée ont été comparés. On a également analysé 3 groupes d'arbres sélectionnés pour leur probable résistance/tolérance aux conditions de steppe et à la pollution industrielle. Le pourcentage de loci polymorphes dans les populations naturelles varie de 0,74 à 0,89 et le nombre d'allèles de 2,4 à 2,7 , alors que les valeurs relevées dans les populations artificielles étaient respectivement de 0,75 à 0,85 et de 2,35 à 2,75. Six populations sur 7 ont montré un déficit d'hétérozygotie $(14,9 \%)$ alors qu'un excès d'hétérozygotie (de 14,6 à 36,9\%) et une diversité allèlique réduite étaient notés dans les groupes d'arbres sélectionnés. La distance génétique de Nei entre populations sélectionnées et populations naturelles est en moyenne de 0,1 . Les paramètres mesurés dans les différents types de populations n'ont pas révélé de dépression de consanguinité. Ces analyses permettent de recommander l'utilisation, comme matériel de base, d'arbres sélectionnés pour entamer d'importants programmes de plantation de Pinus pallasiana dans la steppe ukrainienne, y compris dans le zones atteintes par la pollution industrielle.

Pinus pallasiana D. Don / steppe ukrainienne / variation alloenzymatique / zones polluées / sélection

\section{INTRODUCTION}

The extensive group of Mediterranean and Balkan black pines is a relict of the Tertiary era. One of these is the Pallas pine, which several authors consider to be a sub-species, namely Pinus nigra ssp. pallasiana (Lamb.), and it grows in the Caucasus and Balkan regions [25]. Debazac [6] divided this pine into three varieties growing in different areas: var. pontica Koch. in Crimea, var. caramanica Loud. in Anatolia and var. Fenzeii Ant. and Ky on the Taurus range. Dallimore and Jackson
[7] had previously described these three varieties as synonyms of P. nigra var. caramanica (Loudon) Rehder. The Crimean sub-species of black pine that has been widely used for afforestation programs in the Ukraine steppes is considered in this paper.

The usual explanation of the lack of forests or absence of extensive forests in the Ukraine steppes, an area of 240000 square kilometres, is related to the particular ecological conditions found there. The region is characterised by steppe phytocoenoses [2], fertile black soils (6-9\% humus content) and an arid

\footnotetext{
* Corresponding author: yaroslavpv@ skif.net
} 
continental climate receiving 300-450 mm of mean annual rainfall. In this environment, forestation has always been a difficult and complicated task $[2,21]$. In the final decades of the 20th century afforestation programmes were started using $P$. pallasiana from Crimea, whose adaptive potential was well known to the local foresters. The comparatively good plasticity of this species can be explained by its relatively high genetic variation levels, which were observed by Silin and Goncharenko [22] and which they found also within the Crimea populations. They defined this pine as one of the most variable within the genus Pinus.

Moreover, most of the afforestation programs were carried out in the southern steppe regions of Ukraine, thereby exceeding the range of Crimean natural populations [3].

Natural basic materials are generally considered to have the potential to supply seeds and seedlings with sufficient genetic diversity parameters but, in any case, monitoring these parameters and any possible genetic losses is of great importance for the conservation and sustainability of the artificial stands. Several selection factors may affect a lot of the propagation materials used in afforestation programs and some of the most focal usually considered are extreme climatic conditions and standard nursery practices. This second factor, especially, can often be of great importance, along with the nursery networks. Indeed, unsuitable seedlings are usually screened and rejected before distribution and this might result in dramatic changes to the original genetic structure of the propagation material. Moreover, the Pinus pallasiana considered by us was used in a steppe environment with a very extreme climate. These steppe plantations were often included in polluted urban and industrial areas, where the selection pressure can be chronically strong [14]. As a consequence, the structural and genetic parameters of populations growing in steppe and polluted environments could have worsened when compared to other natural and artificial populations. Changes due to air and soil pollution were also detected in the gene pool structures of forest species by Bergmann and Scholz [5], by Geburek and Scholz [9] and by Bergmann and Hosius [4]. Geburek et al. [10] compared Pinus sylvestris trees which were tolerant and sensitive to air pollution. They investigated possible isozyme gene loci involved in sensitivity against environmental stress and found a strong selection effect. For the same species, Korshikov et al. [15] confirmed the occurrence of selection pressure determined by pollution on the genetic structure of populations.

By using isozyme analysis, a selection effect by air pollution on gene pools of different species (Silver fir, Norway spruce, and European beech) was also demonstrated by Longauer et al. [17] and by Müller-Starck [19].

Given these earlier results, it is clearly important that, before selection and improvement programs go ahead [3, 13], the genetic potential of possible basic materials needs to be investigated and compared to a reference system of natural populations.

This comparison can also be very important in the case of Pinus pallasiana, in order to monitor the effects of selection pressure on basic materials, due not only to climatically extreme and polluted conditions, but also to the effects of the selection/ improvement carried out by foresters.

The specific goal of this investigation was to compare the allozyme variation parameters of a $P$. pallasiana natural reference

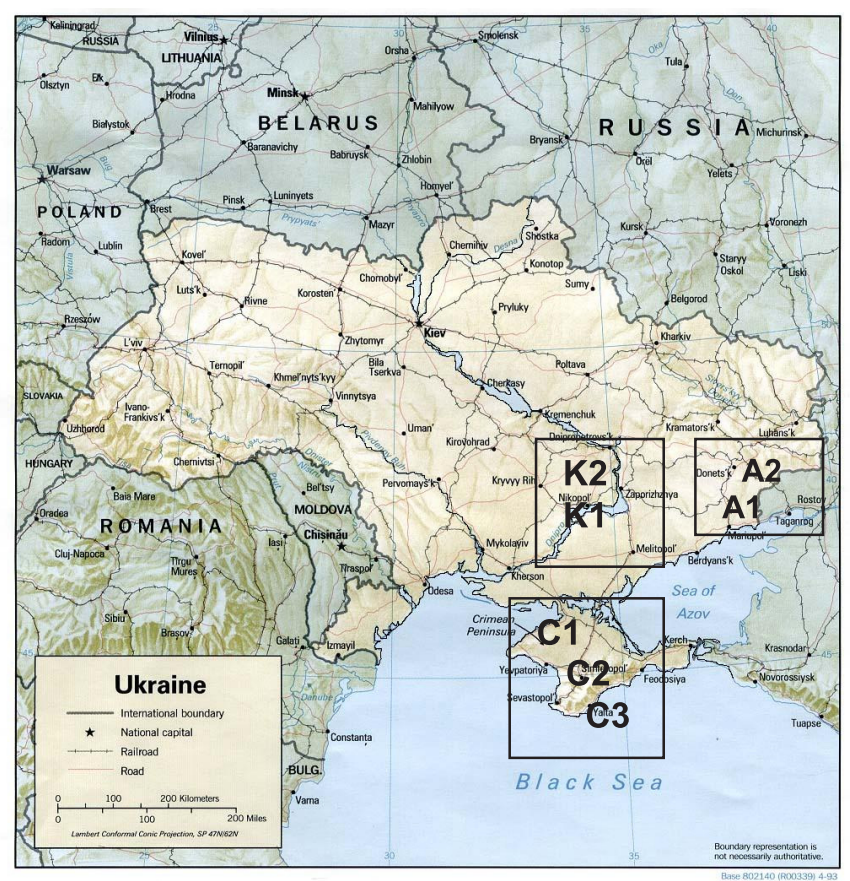

Figure 1. Location of Black Pine natural stands and plantations examined (see also Tab. I).

system, namely the Crimean natural populations, with artificial stands growing in environments suffering from various forms of pollution, with a view to further selection and improvement.

This contribution reinforces and enhances the methods used in Ukraine for selecting basic materials tolerant/resistant to pollution.

\section{MATERIALS AND METHODS}

\subsection{Plant material}

The genetic parameters of ten sub-populations (Tab. I), belonging to three larger $P$. pallasiana Ukraine natural and artificial provenances, were compared. The comparison method was based on the common homeostatic principle that a higher degree of individual genetic multiplicity supports higher viability [16]. On this basis it would be assumed that large natural populations provide both a source of this multiplicity and a reference system for monitoring diversity within artificial populations.

Artificial pine populations of the Ukraine steppe and groups of trees selected within natural and artificial populations were compared to a reference system of natural Crimean stands in order to determine possible losses of genetic diversity.

The main locations of the larger provenances (Fig. 1 and Tab. I) are: (a) the southern macro-slope of the main range of the Crimea mountains, 3 natural stands coded C; (b) the Ukraine steppe near the town of Mariupol, close to the Azov Sea coast, 2 stands coded An; and (c) the interior steppe near the town of Krivorozhje, 2 stands coded Kn. All the artificial populations were certified by the local forest services as provenances from Crimea and their main characteristics are summarised in Table I. 
Table I. Mean traits of Pinus pallasiana examined populations (see also Fig. 1).

\begin{tabular}{|c|c|c|c|c|c|c|}
\hline Code & Region & Population name & Origin & Pollution & Purpose & No. of sampled trees \\
\hline A1 & Azov Coast & Mariupol 1 & Crimea & Gas, sporadic & Steppe re-afforestation & 55 \\
\hline $\mathrm{A} 2$ & Azov Coast & Mariupol 2 & Crimea & Gas, chronic & Steppe re-afforestation & 50 \\
\hline TA & Azov & Selected trees & Crimea & Yes & Tolerance to pollution & 20 \\
\hline $\mathrm{C} 1$ & Crimea & Nikita & Eastern Crimea, 400-900 m & No & Natural population & 76 \\
\hline $\mathrm{C} 2$ & Crimea & Iograph & $\begin{array}{c}\text { Central Crimea, } \\
400-1200 \mathrm{~m}\end{array}$ & No & Natural population & 51 \\
\hline $\mathrm{C} 3$ & Crimea & Alupka & $\begin{array}{l}\text { Western Crimea, } \\
400-1200 \mathrm{~m}\end{array}$ & No & Natural population & 37 \\
\hline $\mathrm{TC}$ & Crimea & Selected trees & Crimea & No & Clonal seed orchard & 20 \\
\hline $\mathrm{K} 1$ & Krivorozhje & Mines & Ukraine & $\begin{array}{l}\text { Chronic, soil } \\
\text { heavy metals }\end{array}$ & Wasted area afforestation & 50 \\
\hline $\mathrm{K} 2$ & Krivorozhje & Krivoy Rog & Ukraine & Urban, lower level & Ricreational area & 50 \\
\hline TK & Krivorozhje & Selected trees & Crimea & Yes & Tolerance to pollution & 20 \\
\hline
\end{tabular}

The Crimean natural reference system was formed by trees aged from 80 to 120 years old and over. Provenances were sampled at different ranges of elevation and slope aspect: 400-900 m, eastern slope, Nikita $\left(\mathrm{C}_{1}\right) ; 400-1200 \mathrm{~m}$, southern slope, Iograph Mountain $\left(\mathrm{C}_{2}\right)$; and 400-1200 m, western slope, Alupka $\left(\mathrm{C}_{3}\right)$.

Populations C1 (Nikita) and C2 (Iograph) belong to the same set of 8 natural stands studied by Silin and Goncharenko [22]. However, only for $\mathrm{C} 2$ was there clear correspondence among the sampled populations, whilst our $\mathrm{C} 1$ included both the populations which they had named Nikita 1 and Nikita 2.

The Azov Sea plantations are exposed to both sporadic $\left(A_{1}\right)$ and chronic $\left(A_{2}\right)$ emissions released by the largest metallurgical plants in Europe. On the other hand, the plantations sampled in the Krivorozhje region are located on mining dumps, dealing with thermal treatment of iron-ore and metal smelting $\left(\mathrm{K}_{2}\right)$, and on a recreation area in Krivoy $\operatorname{Rog}\left(\mathrm{K}_{1}\right)$, where pollution is mostly of urban origin. The trees in $\mathrm{K} 1$ are more than 40 years old and those in $\mathrm{K} 2$ aged approximately 20 years.

Between 1995 and 1999 a selection programme for tolerance/ resistance to air and soil pollutants was started across A1, A, 2, K1 and K2. As a result of this screening, 20 trees, possibly the most tolerant to air pollutants, were selected within the Azov Sea coast populations and 20, possibly the most tolerant to urban pollution and to soils containing heavy metals, were selected across the Krivorozhje stands. Selection was made by using phenotypic indicators (i.e. growth, vigour, health of crowns etc.) and the selected populations were coded TA and TK for the Azov and Krivorozhje regions respectively. The selected trees were characterised by their relatively high seed production and their high germinating capacity of seeds (70-90\%). They were considered to offer a possibly good genetic base for further improvement and breeding.

At the same time a set of 20 plus trees across the Crimean natural populations was selected phenotypically according to traditional parameters (vigour, stem form etc.) and grafted to establish a clonal seed orchard. These clones were considered as a selected reference population and coded TC.

The genetic variation was estimated by isozyme marker analysis performed on all the populations mentioned above.

\subsection{Allozyme analysis}

At least 5 cones per tree were collected from 429 pine trees to extract seeds for electrophoretic analysis.
Enzymes were extracted from haploid mega-gametophytes using an 0.15 M Tris-glycine $\mathrm{pH} 8.3$ buffer, containing $0.003 \mathrm{M}$ ethylendiamin-tetracetate disodium salt, $0.002 \mathrm{M}$ diethyl-ditio-carbamic acid disodium salt and $0.003 \mathrm{M}$ dithio-threitol. The homogenates were used in electrophoresis in $7.5 \%$ polyacrylamid gel vertical plates $(\mathrm{pH} 8.9)$ using a Tris-glycine electrode buffer ( $\mathrm{pH} 8.3$ ).

The enzyme activity zones were stained according to Korochkin et al. [12], Goncharenko et al. [11], with insignificant modifications. Nine enzyme systems were analyzed: alcohol dehydrogenase (ADH, E. C. 1.1.1.1), aspartate-amino-tranferase (AAT, E. C. 2.6.1.1), glutamate-dehydrogenase (GDH, E. C. 1.4.1.2), diaphorase (DIA, E. C. 1.6.4.3), malate-dehydrogenase (MDH, E. C. 1.1.1.37), superoxidedesmutase (SOD, E. C. 1.15.1.1), acid phosphatase (ACP, E. C. 3.1.3.2), leucine-amino-peptidase (LAP, E. C. 3.4.11.1) and formiatdehydrogenase (FDH, E. C. 1.2.1.2). On average 8 endosperms per tree were analysed, and 16 endosperms in the case of homozygous genotypes. Allelic variants were revealed by the analysis of their segregation in haploid mega-gametophytes of heterozygous trees [8].

\subsection{Statistical analysis}

The genetic variation was assessed by the most frequently used statistical parameters for population-genetic analysis and computed by using Biosys-1.7 software [24]: allelic richness (n.a.), allele frequencies $(a . f$.$) , percentage of polymorphic loci after 99 \%$ criterion $(P \%)$, mean number of alleles per locus $(n$.$) , values of observed (\mathrm{Ho})$ and expected heterozygosity $(\mathrm{He})$, Wright's F-statistics and Nei's G-statistics parameters, and Nei's [14] genetic distance coefficient. The standard $\chi^{2}$ test was also used to assess the allelic heterogeneity and this parameter was assessed by comparing the larger pooled provenances with each single group of selected trees (namely TC, TA, TK). Indeed, these groups were selected by foresters across the larger provenances and not within separated stands.

\section{RESULTS}

\subsection{General aspects}

The total number of loci examined was 20, of which 18 were polymorphic.

Loci SOD-2 and SOD-3 proved to be monomorphic in all the samples of $P$. pallasiana studied, and variation for locus SoD-1 was noted in $\mathrm{C}_{3}$ only (Alupka). 
Table II. Synthesis of the allelic richness and rare allele distribution across the population examined.

\begin{tabular}{|c|c|c|c|c|c|}
\hline $\begin{array}{l}\text { Region and } \\
\text { population code }\end{array}$ & $\begin{array}{l}\text { Total No. of alleles detected } \\
\text { within population }\end{array}$ & $\begin{array}{l}\text { Averaged No. } \\
\text { per region }\end{array}$ & $\begin{array}{l}\text { Differences compared } \\
\text { to the region average } \%\end{array}$ & $\begin{array}{c}\text { Rare alleles } \\
\text { (frequency } 0.05 \text { ) }\end{array}$ & $\begin{array}{l}\% \text { of rare alleles on the } \\
\text { total No. of alleles }\end{array}$ \\
\hline Azof Sea coast & & 48 & & & \\
\hline A1 & 46 & & & 15 & 32 \\
\hline A2 & 50 & & & 17 & 34 \\
\hline TA & 41 & & -7 & 6 & 14 \\
\hline Crimea & & 51 & & & \\
\hline $\mathrm{C} 1$ & 54 & & & 17 & 31 \\
\hline $\mathrm{C} 2$ & 51 & & & 18 & 35 \\
\hline $\mathrm{C} 3$ & 48 & & & 13 & 27 \\
\hline $\mathrm{TC}$ & 39 & & -30 & 5 & 12 \\
\hline Krivorozhje & & 54 & & & \\
\hline K1 & 54 & & & 18 & 33 \\
\hline $\mathrm{K} 2$ & 54 & & & 14 & 25 \\
\hline TK & 48 & & -12 & 12 & 25 \\
\hline
\end{tabular}

As a result of the analysis of 9 enzyme systems in the pooled sampling of $429 P$. pallasiana trees, 73 electrophoretic allelic variants were revealed, 49 of which were shared by the populations examined.

Most of the alleles of polymorphic loci were common to the overwhelming majority of $P$. pallasiana samples analysed. With the exception of loci AAT-2 and MDH-4, the most common alleles had frequencies higher than 0.500 .

As could be reasonably expected, the greatest richness of allelic variants (Tab. II) should have been among the Crimean provenances. However, this was observed only when both the Crimea and Azov Sea coast materials were compared. Indeed, the Krivorozhje populations (K1 and K2) showed an average richness greater than the other groups of populations.

The selected groups of trees (TA, TC, TK) also showed the same respective trends and ranking in richness. In any case, a general loss of alleles was evident everywhere within those populations.

The distribution of rarer alleles was, in general, similar across all the examined provenances. On average about $30 \%$ of the allelic richness was to be considered rare (Tab. II). Rare alleles were revealed within each of the three geographical areas. Three rare alleles were only recorded in the Crimea populations, whilst one was found in the Azov plantation and four in the Krivorozhje plantation. No rare alleles typical of these groups were found within the three groups of selected trees (TA, TK, TC). With regard to the amount of rarer alleles, no wide differences were noted between TA and TC, whilst TK showed the largest amount of allelic variants to be noted as rare.

\subsection{The natural reference system and the artificial populations}

The allele frequencies and heterozygosity (Tab. III) showed an absence of geographical trends among the natural populations and the plantations.
The percentage of polymorphic loci varied from 0.74 to 0.89 in the Crimea natural populations. The mean number of alleles varied from 2.42 to 2.74 .

These parameters did not vary, or varied only in a very narrow range, within the artificial plantations of the Azov Sea coast $\left(\mathrm{A}_{n}\right)$ and Krivorozhje $\left(\mathrm{K}_{n}\right)$ and generally presented good characteristics compared to the natural populations.

The heterozygosity of the most variable loci MDH-3, DIA-4, GOT-2, DIA-1, ACP and of the less variable SOD-1, AAT-1, $\mathrm{MDH}-2, \mathrm{GDH}$, varied in a stochastic way across all the populations.

Divergences from the Hardy-Weinberg equilibrium were significant for C1, C3, A1, A2 and K2 (Tab. III).

All cases of significant divergences from the Hardy-Weinberg equilibrium have to be related to a deficiency of heterozygotes (Tabs. III and IV). It is notable that the unbalanced distribution of genotypes in locus $\mathrm{MDH}-4$ is characteristic across all the studied pine populations, including the clonal seed orchard (TC).

The values of observed and expected heterozygosity were only slightly different in the natural populations of $P$. pallasiana studied in Crimea. In these populations the mean value of the observed heterozygosity $(\mathrm{Ho}=0.20)$ was $20.5 \%$ lower than the value recorded after Silin and Goncharenko [22]. In one of the Azov plantations (A2) and one of the Krivorozhje plantations (K2), the values of $H$ o found were similar to the natural populations. In the other Azov plantation, $\mathrm{A}_{1}$, these values were significantly lower than in two out of the three natural populations (C1 and $\mathrm{C} 2$ ). In $\mathrm{K} 2$, instead, they were higher than these populations. The mean expected heterozygosity was $12.7 \%$ lower $(H e=0.22)$ in the studied populations than in the earlier studies [22]. Significant differences in $\mathrm{He}$ were found for the Azov Sea coast plantation $\mathrm{A}_{1}$ only when these were compared to the natural populations.

The structure analysis of the $P$. pallasiana natural and artificial populations was carried out using Wright's F-statistics and Nei's G-statistics. Both these indices indicated a deficiency 
Table III. Values of the main genetic parameters in Crimea P. pallasiana natural populations, steppe Ukrainian plantations and selected groups.

\begin{tabular}{|c|c|c|c|c|c|c|}
\hline \multirow{2}{*}{ Stand } & \multirow{2}{*}{ n. $t$. } & \multirow{2}{*}{$\left(\mathrm{P}_{0,99}\right)$} & \multirow{2}{*}{$n}$. & \multicolumn{2}{|c|}{ Mean heterozygosity } & \multirow{2}{*}{ FIS } \\
\hline & & & & $\left(\mathrm{H}_{0}\right)$ & $\left(\mathrm{H}_{\mathrm{e}}\right)$ & \\
\hline $\mathrm{C} 1$ & 76 & 0.737 & 2.737 & $\begin{array}{c}0.205 \\
(0.018)\end{array}$ & $\begin{array}{c}0.232 \\
(0.020)\end{array}$ & $0.116^{* * *}$ \\
\hline $\mathrm{C} 2$ & 51 & 0.737 & 2.474 & $\begin{array}{c}0.202 \\
(0.022)\end{array}$ & $\begin{array}{c}0.209 \\
(0.022)\end{array}$ & 0.033 \\
\hline $\mathrm{C} 3$ & 37 & 0.895 & 2.421 & $\begin{array}{l}0.188 \\
(0.26)\end{array}$ & $\begin{array}{c}0.217 \\
(0.028)\end{array}$ & $0.134 * * *$ \\
\hline TC. clones* & 20 & 0.700 & 2.000 & $\begin{array}{c}0.235 \\
(0.032)\end{array}$ & $\begin{array}{c}0.220 \\
(0.034)\end{array}$ & -0.068 \\
\hline $\mathrm{A} 1$ & 55 & 0.750 & 2.350 & $\begin{array}{c}0.157 \\
(0.020)\end{array}$ & $\begin{array}{c}0.175 \\
(0.020)\end{array}$ & $0.103^{* * *}$ \\
\hline A2 & 50 & 0.750 & 2.550 & $\begin{array}{c}0.185 \\
(0.022)\end{array}$ & $\begin{array}{c}0.217 \\
(0.024)\end{array}$ & $0.147 * * *$ \\
\hline TA. selected trees** & 20 & 0.750 & 2.150 & $\begin{array}{c}0.215 \\
(0.036)\end{array}$ & $\begin{array}{c}0.227 \\
(0.038)\end{array}$ & 0.053 \\
\hline K1 & 50 & 0.850 & 2.750 & $\begin{array}{c}0.251 \\
(0.024)\end{array}$ & $\begin{array}{c}0.239 \\
(0.024)\end{array}$ & -0.050 \\
\hline K2 & 50 & 0.800 & 2.700 & $\begin{array}{c}0.194 \\
(0.022)\end{array}$ & $\begin{array}{c}0.228 \\
(0.024)\end{array}$ & $0.149 * * *$ \\
\hline TK. selected trees** & 20 & 0.850 & 2.450 & $\begin{array}{c}0.210 \\
(0.038)\end{array}$ & $\begin{array}{c}0.225 \\
(0.038)\end{array}$ & 0.067 \\
\hline
\end{tabular}

* Phenotypically selected; $* *$ selected as tolerant/resistant to pollution; $n . t .:$ number of trees; $P_{0,99}$ : percentage of polymorphic loci; $n .:$ mean number of alleles per locus; FIS: Wright's fixation index (coefficient of inbreeding) computed as $F I S=1-H_{0} / H_{e}$, significant deficiency or excess of heterozygotes $(P<0.01)$ are marked $* * *$.

of heterozygotes in most of the examined populations. Significant deficiencies of heterozygotes, from 11.6 to $14.9 \%$, were noted within the natural populations $\mathrm{C} 1$ and $\mathrm{C} 3$ and in three artificial stands (A1, A2 and K2). When the fixation indices were pooled according to the greater regions (Tab. V), the highest heterozygosity deficiency was observed in the Azov Sea coast populations and Crimea populations $(7.1 \%$ and $6.6 \%$ respectively), whilst the best situation was noted in the other set of artificial populations in the Krivorozhje region where the deficiency was only $2 \%$. The differences between Krivorozhje and the others were thus significant (Tab. V). Genetic differentiation of the populations and plantations investigated was low, as shown by the small values of Fst, Gst and Nei's [20] genetic distance $\left(D_{N}\right)$ coefficients. In Crimea, $D_{N}$ varied within the range of 0.004 to 0.012 and averaged to 0.009 (Fig. 2). This coefficient varied within a rather narrow range $(0.006$ to 0.017 , averaged to 0.010 ) when the $\mathrm{C} n$ natural populations were compared to the Azov and Krivorozhje plantations respectively. This analysis showed that most of the $P$. pallasiana plantations of the steppes $\left(\mathrm{A}_{1}, \mathrm{~A}_{2}, \mathrm{~K}_{2}\right)$ retain the essential genetic diversity that occurs within the natural pine populations of Crimea.

\subsection{The selected populations}

As could be reasonably expected, the selection of tolerant/ resistant trees and their small number, only 20 per provenance (TA, TC, TK), resulted in a loss of alleles. The clonal seed orchard established with plus trees selected from the Crimea

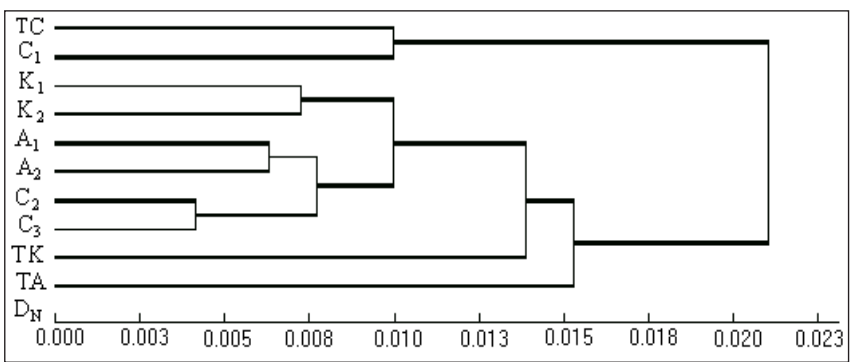

Figure 2. Cluster dendrogram based on Nei's genetic distances [10] measured between $P$. pallasiana samples.

populations (TC) showed the lowest number of alleles (39). This was lower than the number in the selected population TA from the Azov Sea coast (41 alleles) and in the other population TK from Krivorozhje (48 alleles). These groups of selected trees showed a general trend to change the expected heterozygosity for some loci (i.e. MDH-4 and DIA-2) compared to the original populations. Values of $\mathrm{He}$ for $\mathrm{MDH}-4$ were about 1.9 times higher when TC was compared to the Crimea populations $(\mathrm{C} 1, \mathrm{C} 2$, C3), from 1.9 to 4.8 times when TA was compared to the Azov plantations (A1, A2), and from 1.6 to 1.8 times when TK was compared to Krivorozhje plantations (K1, K2). On the contrary, values for DIA-2 were about 2.6 times lower when TC 
Table IV. Comparative analysis of alleles heterogeneity after a $\chi^{2}$ criterion within the $P$. pallasiana natural populations, artificial stands and selected materials. Monomorphic loci were excluded from the table.

\begin{tabular}{|c|c|c|c|c|c|c|c|}
\hline \multirow[t]{2}{*}{ Locus } & \multirow{2}{*}{$\begin{array}{l}\text { Pooled Crimean } \\
\text { natural populations } \\
\text { C1, C2, C3 }\end{array}$} & \multicolumn{2}{|c|}{ Crimean Provenance plantations } & \multicolumn{4}{|c|}{ The selection group of plants - original populations and plantations } \\
\hline & & $\begin{array}{c}\text { Pooled Azov sea } \\
\text { coast A1, A2 }\end{array}$ & $\begin{array}{c}\text { Pooled Krivorozhje } \\
\text { K1, K2 }\end{array}$ & $\begin{array}{l}\text { Crimea } \\
\text { TC }\end{array}$ & $\begin{array}{c}\text { Azov Sea coast } \\
\text { TA }\end{array}$ & $\begin{array}{c}\text { Krivorozhje } \\
\text { TK }\end{array}$ & $\begin{array}{c}\text { Pooled } \\
\text { TC, TA, TK }\end{array}$ \\
\hline Got-1 & $8.77 *(2)$ & n.s. & n.s. & n.s. & n.s. & n.s. & n.s. \\
\hline Mdh-4 & $23.75^{* *}(8)$ & $23.48 * * *(4)$ & $29.67 * * *(4)$ & $18.73 * * *(4)$ & n.s. & n.s. & $16.56^{*}(6)$ \\
\hline Dia-1 & $16.03 * *(6)$ & n.s. & n.s. & n.s. & n.s. & $7.80 *(2)$ & n.s. \\
\hline Dia-4 & n.s. & n.s. & $6.5^{*}(2)$ & n.s. & n.s. & n.s. & n.s. \\
\hline Acp & n.s. & $9.84 *(3)$ & n.s. & $16.40 * * *(3)$ & n.s. & n.s. & n.s. \\
\hline Adh-1 & $12.67 * *(6)$ & $13.61 * *(4)$ & n.s. & n.s. & n.s. & n.s. & n.s. \\
\hline Adh-2 & n.s. & n.s. & $11.44 * *(3)$ & n.s. & n.s. & n.s. & n.s. \\
\hline Fdh & n.s. & $14.24 * *(3)$ & n.s. & n.s. & $6.65 *(2)$ & n.s. & n.s. \\
\hline Multilocus estimation & $121.06 * *(88)$ & $98.29 * * *(48)$ & $100.67 * * *(52)$ & $60.01(45)$ & $30.55(34)$ & $46.04(46)$ & $82.74(68)$ \\
\hline
\end{tabular}

* Significance level of $95 \%$, ** significance level of $99 \%$, *** significance level of $99.9 \%$, a number of degrees of freedom is stated in brackets.

Table V. Mean values of Wright's F- and Nei's G-parameters for the Crimean $P$. pallasiana natural populations and plantations.

\begin{tabular}{lcccc}
\hline Provenance & $\mathrm{F}_{\text {is }}$ & $\mathrm{F}_{\text {it }}$ & $\mathrm{F}_{\text {st }}$ & $\mathrm{G}_{\text {st }}$ \\
\hline Crimean populations & 0.066 & 0.077 & 0.013 & 0.016 \\
Azov sea coast plantations & 0.071 & 0.078 & 0.007 & 0.011 \\
Krivorozhje plantations & 0.020 & 0.028 & 0.009 & 0.010 \\
\hline
\end{tabular}

was compared to $\mathrm{C} 1, \mathrm{C} 2$ and $\mathrm{C} 3$, from 15 to 2.4 times lower when TA was compared to A1 and A2, and 18 times lower when TK was compared to $\mathrm{K}_{1}$ and $\mathrm{K}_{2}$.

Allele heterogeneity was observed within the three natural populations of Crimea $P$. pallasiana $(\mathrm{C} 1, \mathrm{C} 2, \mathrm{C} 3)$ for 4 loci (Tab. IV). The same was observed when the artificial populations of the Azov Sea coast were examined. Heterogeneity in the Krivorozhje plantations was reduced to 3 loci.

Heterogeneity with significant differences was mainly observed for locus MDH-4 (Tab. IV). This was evident when the selected groups TC, TA, TK were pooled. The two selected populations from Azov and from Krivoroje showed polymorphic loci percentages relatively similar to the provenances they were selected from, whilst in TC the value was relatively lower. On the other hand, the mean number of alleles was notably lower: from 18.4 to $27 \%$ in TC, from 9.5 to $15.7 \%$ in TA coast and from 9.3 to $11 \%$ in TK (Tab. III). The level of heterozygosity was very similar in all the $P$. pallasiana stands, with the exception of the Azov Sea coast materials which seemed genetically poorer. Values of $H o$ were 14.4 to $25 \%$ higher in TC than in the Crimea natural populations. Ho was significantly higher in TA than in the Azov Sea coast plantations $\left(\mathrm{A}_{1}, \mathrm{~A}_{2}\right)$ and the values were higher than those supplied earlier for this area [14].

Excess of heterozygotes, even if not significant (6.8\%), was noted in TC only. Within TA and TK, however, a lower deficiency of heterozygotes was found than in their original stands. Values of $\mathrm{Ho}$ (9.3 to $11.9 \%$ ) and in particular $\mathrm{He}$ (2.3 to $3.2 \%$ ) observed in the selected populations were notably lower than in their stands.
The degree of genetic differentiation of selected groups (TC, TA, TK) and of plantations (A1, A2 and K1, K2) was lower than the natural populations of $P$. pallasiana $(\mathrm{C} 1, \mathrm{C} 2, \mathrm{C} 3)$. Consequently, values of the genetic distance coefficient $\mathrm{D}_{\mathrm{N}}$ varied from 0.009 to 0.024 (average: 0.015 ) between TC and C1, C2, C3. The groups of selected trees (TC, TK, TA) were relatively diverged $\left(D_{N}=0.017\right.$ to 0.035 , mean 0.026) (Fig. 2).

\section{DISCUSSION AND CONCLUSION}

The variation characteristics outlined for $P$. pallasiana natural populations by this study differed from those after Silin and Goncharenko [22]. Indeed, only two of our reference system populations can be considered common to these authors. On one hand, the wider number of natural populations they examined may have contributed to their finding greater genetic variation across Crimea. No problem should arise from the number of trees per population which we have sampled. Indeed, while the number of samples was similar to Silin and Goncharenko [20] for Nikita, it was double for our work in Iograph. On the other hand, even if the larger number of loci examined by these authors could have contributed to detecting more variation, the acrilamide gel electrophoresis that we used improved the detection of at least 54 alleles/18 loci. The starch gel system used earlier by these authors allowed a ratio of 55 alleles/20 loci.

The values of the main genetic parameters detected by us for C2 (Iograph) were relatively close to the earlier studies, whilst Nikita (C1) showed a significant excess of homozygotes. This unbalanced state, which we observed in Nikita, may be more reasonably explained by the mature age of the trees sampled. Other demographic factors, difficult to evaluate in this analysis, probably also played a role. Moreover, the progressive reduction and fragmentation of the range could have induced the high withinpopulation variation detected by Silin and Goncharenko [22].

The genetic variation of conifers is generally lower in artificial stands than in natural populations, [1, 18, 22]. This comparative investigation within the Crimean $P$. pallasiana showed the ability of some artificial populations ( $\mathrm{K} n$, Ukrainian steppe) 
to preserve better the potential of their natural provenance populations. Several considerations need to be made with regard to the generally better situation presented by the Krivorozhje provenance. This could depend on a more efficient seed collection organisation, as well as a full ripening period for fructification in the original stands. In addition, the original genetic structure of the basic materials could have played a role in establishing the suitable variation status detected within. Such positive effects on artificial population genetic structures are not usually always possible. Very often selection factors of a natural or human origin can greatly modify the genetic parameters. Variation can be depressed by these factors, as shown by MüllerStarck [19] for natural beech populations in Germany, and by Geburek et al. in Pinus sylvestris trials [10]. This situation was also outlined by Bergmann and Scholz [5] for Norway spruce and by Longauer et al. [17] for Norway spruce, European silver fir and beech. Korshikov et al. [15] also found in Pinus sylvestris a slightly lower level of genetic diversity in damaged populations than in populations not exposed to the effects of pollutants.

No relationships were found through our work for AAT and GDH with sensitivity or resistance to air pollution, as suggested by Geburek et al. [10].

Even though structurally unbalanced, the Azov sea coast provenances showed almost similar polymorphism to the natural populations of Crimea. Lower diversity values in this population could arise from several environmental factors, both natural and caused by pollution, near the plantation site, as well as possible differences in seed quality as determined by the year of collection, the number of sampled trees and so on.

All our results agree with the higher ecological plasticity of $P$. pallasiana as suggested by Korshikov [13]. The Pallas pine shows generally good ability to preserve its original variation and structure in artificial stands, even when under strong selective pressure due to pollution. This was also partially true after strict criteria were used for selecting plus trees or possibly tolerant/resistant phenotypes. Selected populations showed a reduction in their variation compared to their respective provenance. Indeed, it was evident that the number of alleles was generally lower in TC, TA, and TK. The reduction of rarer alleles was evident in these sub-populations: about three times in $\mathrm{TC}$ and TA, only once in TK. This reduction was probably due to several factors, such as the size of the selected populations and/or the selection effect on some alleles, as previously demonstrated by a number of authors [5, 10, 13-15, 23]. Nevertheless, the genetic structure of these selected materials, as shown by Wright's FIS, was relatively better and more balanced when compared to their provenances. This would agree with other experiences where greater allelic diversity and higher levels of expected heterozygosity were recorded by some researchers in seed orchards when compared to natural populations [18, 23].

If we assume heterozygosity is the best possible tool for the sustainability of artificial populations [16], collecting seeds or selecting superior phenotypes in populations where deficiency of heterozygosity was noted can adversely affect the genetic structure of their offspring. In the same way, the excess of heterozygotes revealed in $\mathrm{TC}$, as well as in $\mathrm{K} 1$, will reduce possible risks of inbreeding depression in seed posterity.
Although a general reduction of genetic diversity was found across all the groups of selected trees, the original diversity was essentially preserved. Moreover, the good genetic variation levels preserved in the plantations showed the relatively good quality of the nursery supply system used in Ukraine for $P$. pallasiana.

As a consequence of this study, it is clear that the selected materials TC, TA and TK can be considered as relatively good basic materials for establishing a seed orchard network programme. The main aim will be to produce propagation materials that are more tolerant to the adverse conditions of the Ukrainian steppes, as well as to provide seedlings for urban forestry programs in badly polluted industrial areas.

Acknowledgements: This paper was in the framework of IUFRO WP20213. The authors wish to thank the anonymous referees for their valuable review and Dr. Eric Teissier du Cros, IUFRO's vice President for Science for suggestions, comments and for his support to this activity.

\section{REFERENCES}

[1] Adams W.T., Joly R.J., Allozyme studies in loblolly pine seed orchards: clonal variation and frequency of progeny due to self-fertilization, Silvae Genet. 29 (1980) 1-4.

[2] Belghardt A.L., Forest reproduction in the steppe zone, M. Lesnaya promyshlennost', 1971, 336 p. (in Russian).

[3] Beloborodov V.M., Shiryaev V.I., Patlay I.N., Introduced units in the forest cultures of the country's European part, Lesnoye khoziaystvo 8-9 (1992) 38-39 (in Russian).

[4] Bergmann F., Hosius B., Effect of heavy-metal polluted soils on the genetic structure of Norway spruce seedling populations, Water, Air Soil Pollut. 89 (1996) 363-373.

[5] Bergmann F., Scholz F., The impact of air pollution on the genetic structure of Norway spruce, Silvae Genet. 36 (1987) 80-83.

[6] Debazac E.F., Manuel des Conifères, Engref, Nancy, 1977, pp. 96-97.

[7] Dallimore W., Jackson A.B., A Handbook of Conifers. Edward Arnold Publishers Ltd., London, 1961, pp. 514-517.

[8] Eckert R.T., Joly R.J., Neale D.B., Genetics of allozyme variants and linkage relationships among allozyme loci in 35 eastern white pine clones, Can. J. For. Res. 11 (1981) 573-579.

[9] Geburek T., Scholz F., Über Selektionwirkungen bei Forstpflanzenpopulationen infolge von Luftverunreinigungen, Forstarchiv 56 (1995) 234-238.

[10] Geburek T., Scholz F., Knabe W., Vornweg A., Genetic studies by isozyme gene loci on tolerance and sensitivity in air polluted Pinus sylvestris field trial, Silvae Genet. 36 (1987) 49-53.

[11] Goncharenko G.G., Padutov V.E., Potenko V.V., Guidelines on studying the conifers using enzyme electrophoresis analysis, Homel (1), 1989 (in Russian).

[12] Korockin L.I., Serov O.L., Pudovkin A.I., Genetic of Isozymes, Nauca, Moscow, 1977, 278 p. (in Russian).

[13] Korshikov I.I., Plants adaptation to the technogenously polluted environment conditions, Naukova dumka, Kiev, 1996 (in Russian).

[14] Korshikov I.I., Bychkov S.A., Comparative analysis of genetic variation in 2 groups of $P$. pallasiana trees, differing in the degree of injury due to the pollutants in the city of Mariupol plantations, Cytol. Genet. 35 (2001) 30-35.

[15] Korshikov I.I., Velikoridko T.I., Butilskaya L.A., Genetic structure and variation in Pinus sylvestris L. population degrading due to pollution-induced injury, Silvae Genet. 36 (2002) 45-49.

[16] Lerner I.M., Genetic homeostasys, Oliver and Boyd, Edinbourgh, 1954. 
[17] Longauer R., Gömöry D., Paule L., Karnosky D.F., Manikovska B., Müller-Starck G., Percy K., Szaro R., Selection effects of air pollution on gene pools of Norway spruce, European silver fir and European beech, Environ. Pollut. 115 (2001) 405-411.

[18] Moran G.F., Bell J.C., Matheson A.C., The genetic structure and levels of inbreeding in a Pinus radiata D. Don seed orchard, Silvae Genet. 29 (1980) 190-193.

[19] Müller-Starck G., Genetic differences between "tolerantaù" and "sensitive" beeches (Fagus sylvatica L.) in an environmentally stressed adult forest stand, Silvae Genet. 134 (1985) 241-247.

[20] Nei M., Genetic distance between populations, Amer. Naturalist 106 (1972) 283-292.

[21] Paschenko V.M., The steppe zone. The nature of the Ukrainian SSR - Landscapes and physical and geographic regionalization, Naukova dumka, Kiev, 1985, pp. 122-179 (in Russian).
[22] Silin A.E., Goncharenko G.G., Allozyme variation in natural populations of Eurasian pines. 4. Population structure and genetic variation in geographically related and isolated populations of Pinus nigra Arnold on the Crimean peninsula, Silvae Genet. 45 (1996) $67-75$.

[23] Shigapov Z.H., A comparative genetic analysis of forest seed orchards (plantations) and natural populations of scotch pine (Pinus sylvestris L.), Lesovedeniye 3 (1995) 9-24 (in Russian).

[24] Swofford D.L., Selander R.B., Biosys-1, release 1.7, A computer program for the Analysis of Allelic Variation in Population Genetics and Biochemical Systematics $@$, Swofford D.L., Illinois Natural History Survey, 1989.

[25] Vidakovic M., Conifers. Morphology and variation, Ed. Boro Brekalo, Zagreb, 1991, pp. 496-498.

To access this journal online: www.edpsciences.org 